\title{
Microbial biotechnology review in microbial enzyme production methods, assay techniques and protein separation and purifications
}

\begin{abstract}
Enzymes are one of the most important biomolecules which has a wide range of applications in industrial as well as biomedical field. The most important methods of enzyme production, activity assay techniques and purification systems are reviewed. Submerged fermentations and solid-state fermentations are the two methods widely employed for the production of enzymes. Bacterial and Fungal Enzymes produced are assay using both qualitative assay and spectrophotometric assay to determine the activity. SDS polyacrylamide gel electrophoresis (PAGE) allows the separation of proteins based on their molecular weight using Agarose Gel Electrophoresis and protein can be purified by ammonium sulfate precipitation using Dialysis and Chromatographic techniques. The use of enzymes is growing in the food and

beverage processing industries as they are an essential ingredient in food items.
\end{abstract}

Volume 8 Issue I - 2018

\author{
Daniel Yimer,Adaba Tilahun \\ Ethiopian Institute of Agricultural Research, National \\ Agricultural Biotechnology Research Center, Ethiopia
}

\begin{abstract}
Correspondence: Daniel Yimer, Ethiopian Institute of Agricultural Research, National Agricultural Biotechnology Research Center, Microbial Biotechnology Research Program, PO Box: 2003, Holeta, Addis Ababa, Ethiopia, Email daniyoo23@gmail.com
\end{abstract}

Received: November 26, 2017 | Published: January 02, 2018

Keywords: assay, enzyme, protein purification, SDS-PAGE

Abbreviations: PAGE, polyacrylamide gel electrophoresis; SmF, submerged fermentations; SSF, solid-state fermentations; MnP, manganese peroxidase; $\mathrm{cmC}$, carboxymethyl-cellulose

\section{Introduction}

Enzymes are one of the most important biomolecules which has a wide range of applications in industrial as well as biomedical field. They are important due to their many useful properties. Their development, to a great extent, has been possible due to the availability of microbial sources. Microorganisms are of much attention because they can be produced economically and are amenable to genetic improvement Microbial enzymes have replaced many plant and animal enzymes. ${ }^{1,2}$

They have found application in many industries including foods, beverages, pharmaceuticals, detergents, textiles, leather, chemicals, biofuels, animal feed, personal care, pulp and paper, diagnostics, and therapy. New molecular methods, including genomics and metagenomics, are being employed for the discovery of new enzymes from microbes. Enzymes play a very important part in processing many food and beverage products as well as ingredients used in food and beverage products. The food and beverage industries are among the major industries that manufacture a wide range of food and drinks to cater to the needs of the growing world population. The development of recombinant DNA technology has had a major effect on production levels of enzymes and represents a way to overproduce industrially important microbial, plant, and animal enzymes. It has been estimated that between $50-60 \%$ of the world enzyme market is supplied by recombinant enzymes. In addition, directed evolution techniques have allowed design of enzyme specificities and better performance. However, in this review production, enzyme assay, protein separation and purification should be further explained. ${ }^{3}$

\section{Microbial enzyme production overview}

\section{Enzyme production methods}

Submerged fermentations $(\mathrm{SmF})$ and solid-state fermentations (SSF) are the two methods widely employed for the production of Enzymes.

Submerged fermentation: $\mathrm{SmF}$ is a traditional method for enzyme production from microorganisms which has been used for a longer period of time. In SmF, free-flowing liquid substrates like molasses and broths are used. The end products of the fermentation are liberated into the fermentation broth. Substrate utilization is very rapid in SmF; henceforth, substrate must be provided continuously for this fermentation process. This technique is well suited for the extraction of secondary metabolites from bacteria because it requires high moisture content for their growth. SmF has several advantages in which genetically modified organisms are grown well compared to SSF and media sterilization, purification, and recovery of the end products. Further, the control of process parameters such as $\mathrm{pH}$, temperature, moisture, oxygen transfer, and aeration can be done easily. ${ }^{4}$

Solid state fermentation: Solid-state fermentation (SSF) is suitable for the less moisture content required microorganisms. In SSF, nutrientrich waste materials such as bran, bagasse, and paper pulp can be used as substrate for the microorganisms and they are consumed very slowly and constantly. Hence, there is no need to supply the substrate for longer time. Major advantages of SSF are easy to handle, recovery of higher concentration of products, and generation of lesser effluent. Therefore, SSF is considered as a promising method for commercial enzyme production. $\alpha$-Amylase production by $\mathrm{SmF}$ and solid-state fermentation techniques has been examined for fungal species. The results showed that SSF was well suited for developing countries due to cost-effective production process. ${ }^{5}$ 


\section{Techniques in microbial enzyme assay}

\section{Fungal enzyme assay}

Laccase enzyme: The supernatants obtained after separation of the biomasses should be analyzed for $\mathrm{pH}$ and enzyme activity. Laccase activity should be determined by monitoring the A420 change related to the rate of oxidation of $1 \mathrm{mM} 2,2$-azino-bis-[3-ethylbenzthiazoline6-sulfonate] (ABTS) in 25mM Na-acetate buffer (pH 3.8) (Bourbonnais \& Paice). Assays should be performed in 1-ml cuvette at $20 \pm 1^{\circ} \mathrm{C}$ with adequately diluted culture liquid. One unit of laccase activity should be defined as the amount of enzyme that leads to the oxidation of $1 \mu \mathrm{M}$ of ABTS perminute. ${ }^{6}$

Manganese peroxidase (MnP) activity should be measured by oxidation of Phenol Red (Glenn \& Gold). The 1-ml reaction mixtures contained a $0.89 \mathrm{ml}$ lactate-succinate buffer $(50 \mathrm{mM}, \mathrm{pH} 4.5)$ with manganese sulphate $(0.1 \mathrm{mM})$, phenol red $(0.1 \mathrm{mM})$, egg albumin $(0.1 \%)$, and $0.1 \mathrm{ml}$ of appropriately diluted enzyme preparation. The reaction should initiate with $0.1 \mathrm{mM} \mathrm{H}_{2} \mathrm{O}_{2}$, mixtures should be incubated for $1-5 \mathrm{~min}$ at $20 \pm 1^{\circ} \mathrm{C}$, and then the reaction should be terminated with $50 \mu 14 \mathrm{M} \mathrm{NaOH}$. Absorbance was read at $610 \mathrm{~nm}$. One unit of enzyme activity was expressed as the amount of enzyme required to oxidize $1 \mu \mathrm{mol}$ of Phenol Red in 1min. Activities in the absence of $\mathrm{H}_{2} \mathrm{O}_{2}$ should subtract from the values obtained in the presence of hydrogen peroxide to establish true peroxidase activity. The experiments should be performed at least two times using three replicates.

Cellulases activity assay: Cellulase screening should be carried out using carboxymethylcellulose (CMC) and Whatman No. 1 filter paper strip as substrates.

Carboxymethyl-cellulase (CMCase): Cellulase should be measured using a reaction mixture containing $1 \mathrm{ml}$ of $2 \%$ carboxymethyl-cellulose (CMC) in $0.05 \mathrm{M}$ acetate buffer $(\mathrm{pH} 4.8)$ and $1.0 \mathrm{ml}$ of culture supernatant. The reaction mixture should be incubated at $50^{\circ} \mathrm{C}$ for $10 \mathrm{~min}$ and the reducing sugar produced should be determined by dinitrosalicylic acid- DNS method. The absorbance should be measured at $590 \mathrm{~nm}$, taking glucose as the standard. Blanks should be prepared with inactivated enzymes. One unit of endoglucanase activity is defined as the amount of enzyme releasing $1 \mathrm{mg}$ of reducing sugar permin. Exoglucanase (Avicelase) activity should be determined as described for endoglucanase activity, but the incubation should be carried out with $1 \mathrm{ml}$ of $1 \%$ avicel (Sigma) suspension instead of carboxymethylcellulose. ${ }^{8}$

Filter paper activity (FPA): Cellulase measurement, it is a combined assay for endo and exo $\beta-1 ; 4$ glucanase. Thus, $1 \mathrm{ml}$ of the culture supernatant as an enzyme source should be added to whatman No. 1 filter paper strip $(1 \times 6 \mathrm{~cm} ; 50 \mathrm{mg})$ immersed in $1 \mathrm{ml}$ of $0.05 \mathrm{M}$ sodium acetate buffer of $\mathrm{pH} 4.8$. After incubation at $50^{\circ} \mathrm{C}$ for $10 \mathrm{~min}$, the reducing sugar released should be estimated. One unit of the filter paper (FPA) activity is defined as the amount of enzyme releasing $1 \mathrm{mg}$ of reducing sugar from the filter paper per milliliter perminute of the reaction. ${ }^{9}$

\section{Xylanases activity assay}

Qualitative assay: After inoculation and incubation for 3-4days at $50^{\circ} \mathrm{C}, 1 \%$ Congo red solution should be poured onto the plates. The plates should be incubated for $30 \mathrm{~min}$ at room temperature then they should be washed with $1 \mathrm{M} \mathrm{NaCl}$ solution. Clear zones around the colonies on a red background are taken as the evidence for the xylanase activity.
Spectrophotometric assay: The xylanase activity should be determined by measuring the release of reducing sugars from birchwood xylan $(1.5 \% \mathrm{w} / \mathrm{v})$ using the dinitrosalicylic acid method. Reaction mixture containing $4 \mathrm{ml}$ of a solution $1.5 \%$ of birchwood xylan in acetate buffer $(0.2 \mathrm{M}, \mathrm{pH} 5.0)$ and $0.4 \mathrm{ml}$ of the diluted crude enzyme, should be incubated for $20 \mathrm{~min}$ at $50^{\circ} \mathrm{C}$. Samples were collected at the beginning and the end of enzymatic reactions. The amount of reducing sugar in the reaction tubes should be measured using the dinitrosalicylic acid (DNS) method. The absorbance should be read at $\lambda=535 \mathrm{~nm}$ using spectrophotometer. One unit of xylanase is defined as the amount of enzyme required to release $1 \mu \mathrm{mol}$ of the xylose from xylan in 1minute under the assay condition. ${ }^{10}$

\section{Pectinases activity assay}

Qualitative assay: After 3-4days incubation at $50^{\circ} \mathrm{C}, 1 \%(\mathrm{w} / \mathrm{v})$ cetyl trimethyl ammonium bromide (CTAB) solution should be poured onto the colonies. After $10 \mathrm{~min}$ incubation at room temperature, colonies with clear zones are taken as pectinase producers. ${ }^{11}$

Spectrophotometric assay: Pectinase activity should determined by measuring the increase in absorbance at $235 \mathrm{~nm}$ of the substrate solution $(1 \mathrm{ml}$ of $0.5 \%$ citric pectin in $0.2 \mathrm{M}$ citrate-phosphate buffer, $\mathrm{pH}$ 5.5) hydrolysed by $1 \mathrm{ml}$ of the crude enzymatic extract, at $40^{\circ} \mathrm{C}$ for $1 \mathrm{~h}$. The reaction was halted by adding $3.5 \mathrm{ml} \mathrm{HCl} 0.5 \mathrm{M}$. One enzymatic unit $(\mathrm{U})$ is defined as the amount of enzyme which liberates 1 mol of unsaturated uronide perminute, based on the molar extinction coefficient $\left(\varepsilon 235=5550 \mathrm{M}-1 \mathrm{~cm}^{-1}\right)$ of the unsaturated products. On the other hand, exo-polygalacturonase (Exo-PG) activity should be determined through reduction of groups from citrus pectin using the 3,5-dinitrosalicylic acid (DNS) reagent assay. The reaction mixture, containing $0.5 \%$ citric pectin in $0.025 \mathrm{M}$ acetate buffer ( $\mathrm{pH} 5.0), 1 \mathrm{mM}$ EDTA and the crude enzymatic extract, should be incubated at $50^{\circ} \mathrm{C}$ for 10min and then DNS solution should be added to each tube and boiled for $5 \mathrm{~min}$. After cooling, distilled water should be added and agitated; then, the absorbance at $575 \mathrm{~nm}$ measured. The reductant sugar values determined from a standard curve of monogalacturonic acid. One enzymatic unit $(U)$ is defined by the enzyme quantity which liberates $1 \mathrm{mMol}$ of monogalacturonic acid permin under the described experimental conditions. The enzymatic activity expressed in $\mathrm{U} / \mathrm{g} .{ }^{12}$

\section{Bacterial enzyme assay}

Protease assay: Each isolate should be inoculated in $100 \mathrm{ml}$ nutrient broth containing $1 \%$ casein and incubated for $24 \mathrm{~h}$ on a rotary shaker $(100 \mathrm{rpm})$ at $30^{\circ} \mathrm{C}$. The cells should separate by centrifugation of growth in broth at $5000 \mathrm{rpm}$ for $20 \mathrm{~min}$. The supernatant contained enzyme and should consider as crude enzyme extract. Protease activity should be measured using caseinolytic assay with some modifications. The culture supernatant $(0.1 \mathrm{ml})$ should be incubated in $9 \mathrm{ml}$ of $1 \%$ casein prepared in phosphate buffer $(\mathrm{pH}-7)$ at $30^{\circ} \mathrm{C}$ for $20 \mathrm{~min}$. The reaction should stop by $1.5 \mathrm{ml}$ of trichloroacetic acid $(5 \%$ $\mathrm{w} / \mathrm{v})$. After $10 \mathrm{~min}$ the entire mixture should centrifuge at $5000 \mathrm{xg}$ for $15 \mathrm{~min}$. Absorbance of the supernatant should be measured by modified Folin Ciocalteu method against inactive enzyme. A standard graph should generate using standard tyrosine of 10-100 $\mu \mathrm{gml}-1$. One unit of protease activity is defined as the amount of enzyme, which liberated $1 \mu \mathrm{g}$ tyrosine permin at $30^{\circ} \mathrm{C}$.

\section{Amylases activity assay}

Qualitative assay: After inoculation of isolates, the plates should be incubated for $3-4$ days at $50^{\circ} \mathrm{C}$. Iodine solution $(\mathrm{I} 2=1 \mathrm{~g}, \mathrm{KI}=2 \mathrm{~g} / 300 \mathrm{ml})$ 
should poured on the plates. Clear zones around the colonies indicated the presence of amylase activity. ${ }^{13}$

Spectrophotometric assay: $1 \mathrm{ml}$ of substrate solution containing $1 \%$ $(\mathrm{w} / \mathrm{v})$ soluble starch in $20 \mathrm{mM}$ sodium phosphate buffer $(\mathrm{pH} 6.0)$ and $1 \mathrm{ml}$ of enzyme solution (cell free supernatant) should be incubated at $55^{\circ} \mathrm{C}$ for $3 \mathrm{~min}$ and the reaction should stopped by adding $96 \mathrm{mM}$ 3, 5-dinitrosalicylic reagent boiled and then cooled on ice to room temperature. Absorbance should be measured at $540 \mathrm{~nm}$ using spectrophotometer.

\section{Lipases activity assay}

Qualitative assay: After inoculation of the isolates, the plates should be incubated for $3-4$ days at $50^{\circ} \mathrm{C}$. Opaque halos around the colonies are taken as the indication of lipase activity. ${ }^{14}$

Spectrophotometric assay: Lipase activity should be routinely assayed using $p$-nitrophenyl palmitate ( $p$-NPP) as appropriate substrates. The assay should typically run for $10 \mathrm{~min}$ at $60^{\circ} \mathrm{C}$ before termination by addition of $2.0 \mathrm{ml}$ of $0.2 \mathrm{M} \mathrm{Na}_{2} \mathrm{CO}_{3}$. Liberated $p$-nitrophenol ( $p$-NP) should be determined at $410 \mathrm{~nm}(\varepsilon 410 \mathrm{~nm}: 0.0169 / \mu \mathrm{molcm})$ using a spectrophotometer. Appropriate blanks should be used to subtract the absorbance corresponding to the reaction mixture other than that produced by the specific hydrolysis of $p$-NPP. One international unit (86 IU) of lipase activity is defined as the amount of enzyme needed to liberate $1 \mu \mathrm{mol}$ of $p$-NP perminute under the assay conditions.

Determination of the cellular location of enzyme activity: Cells were grown in $125 \mathrm{ml}$ of $1.0 \%$ yeast extract, $1.0 \% \mathrm{~K}_{2} \mathrm{HPO}_{4}, 1.0 \%$ $\mathrm{NaH}_{2} \mathrm{PO}_{4}$ with $10 \mathrm{~m} \mathrm{MmgCl} 2$ broth in $500 \mathrm{ml}$ baffled flasks at $30^{\circ} \mathrm{C}$ and $120 \mathrm{rpm}$. Cultures were harvested at early stationary phase (approximately 16 hours $)$. A sample $(50 \mathrm{ml})$ of the whole culture was collected and stored in a ice-water slurry (Culture Sample). ${ }^{15}$

The remaining culture was centrifuged $(10,000 \mathrm{x} g$ for 30 minutes at $4^{\circ} \mathrm{C}$ ) and the culture supernatant collected and filter- sterilized by passage through a $0.2 \mathrm{um}$ pore size filter and stored in an ice-water slurry (Supernatant Sample). The cell pellet was resuspended in an equal volume of $10 \mathrm{mM}$ phosphate buffer $(\mathrm{pH} 7.5)$ and a portion collected and stored in ice-water slurry (Cell Sample). The cells were centrifuged $\left(10,000 \mathrm{x}\right.$ g for 30 minutes at $\left.4^{\circ} \mathrm{C}\right)$ and the wash retained in an ice-water slurry (Wash Sample).

The cell pellet was resuspended in an equal volume of buffer (repeat of step 4). A sample of the cells in the remaining suspension was broken using a French Press. The unbroken cells and cell debris were separated from the crude extract by centrifugation $(15,000 \mathrm{x} \mathrm{g}$ for 5 minutes at $4^{\circ} \mathrm{C}$ ). The cells and cell debris were suspended in the original volume of $10 \mathrm{mM}$ phosphate buffer $(\mathrm{pH} 7.0)$ and stored in ice-water slurry (Debris Sample). A portion of the crude extract was stored in ice-water slurry (Crude Extract Sample). ${ }^{16}$

The remaining portion of the crude extract was centrifuged $(100,000 \times \mathrm{g}$ for 60 minutes $)$ at $4^{\circ} \mathrm{C}$ to pellet the membrane fraction. The supernatant fraction was collected and stored in ice-water slurry (Soluble Sample) and the pellet suspended in an equal volume of $10 \mathrm{mM}$ phosphate buffer $(\mathrm{pH} 7.0)$ and stored in ice-water slurry (Membrane Sample). The protease activity and protein concentration was measured and specific activity determined for the following fractions; filtered supernatant, washed cells, crude extract, membrane and soluble (Figure 1). As markers, $\beta$-galactosidase (soluble) and alkaline phosphatase (periplasmic) activities were measured on the same fractions. ${ }^{17}$

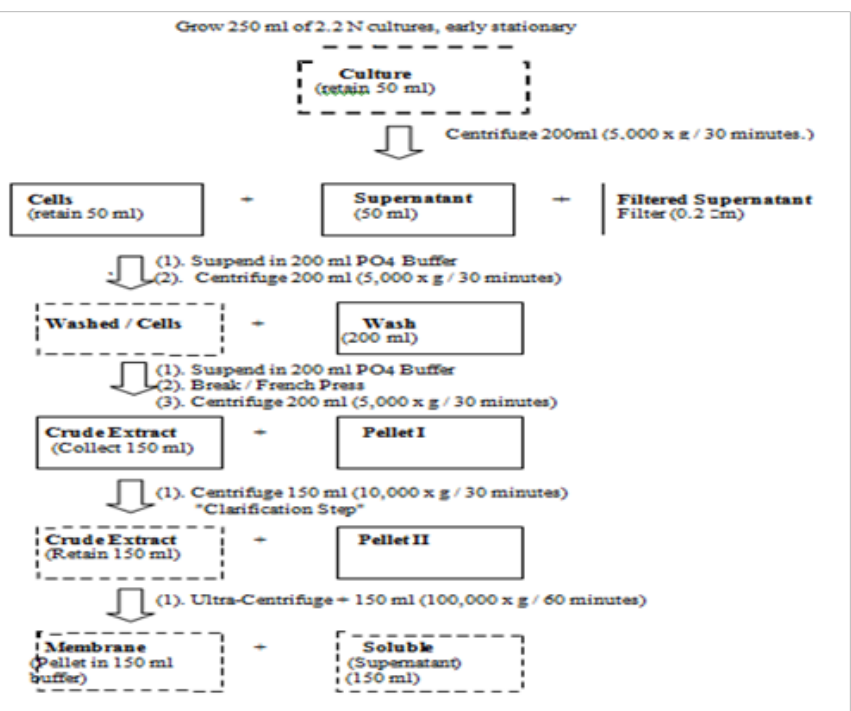

Figure I Fractionation Flow-Chart.

\section{Protein separation and purification}

\section{Protein Separation}

Electrophoretic techniques: SDS polyacrylamide gel electrophoresis (PAGE) allows the separation of proteins based on their molecular weight. This technique can be used to determine whether a given protein is present in a sample, and for assessment of purity of the preparation, for estimation of the approximate quantity of the protein, and for measurement of the size of the protein. Electrophoresis is a process in which molecules are exposed to an electric field and separated on the basis of their differential mobilities in that field.

The observed differential mobility is a result of different charge magnitudes on different molecules, and the result of different resistance to movement through the medium. For molecules with similar shapes, the mobility is proportional to the charge-to-mass ratio of the molecule. For molecules of similar shapes and similar charge-to-mass ratios, the motion through the medium will be proportional to the size of the molecule, because friction increases as a function of size. ${ }^{18}$

After the electrophoresis has been performed, the protein must be detected. The most commonly used method for detecting protein is Coomassie Blue R-250. Coomassie blue is a dye that binds proteins. Staining is performed by placing the gel in a solution of Coomassie blue in acetic acid and methanol. The function of the acetic acid and methanol is to cross-link the proteins into the gel so that they do not diffuse. Following staining of the proteins, the gel is placed in a destaining solution of acetic acid and methanol, which results in removal of the excess Coomassie blue.

An example of an SDS gel is shown at right. Lane 1 in the example is comprised of proteins of known molecular weight called molecular weight standards. Lanes 2, 3, and 4 contain increasing concentrations of an experimental protein sample. Loading increasing amounts of protein makes it possible to see minor impurities, which are difficult to see in lane 2 and fairly obvious in lane 4 . The molecular weight standards can be used to calibrate the migration of proteins of differing sizes on the gel. A commonly used set of molecular weight standards for SDS PAGE experiments is shown in the table below ${ }^{19}$ (Table 1) (Figure 2). 
Table I Standard protein used for SDS-PAGE experiment for protein separation

\begin{tabular}{ll}
\hline Standard protein (Da) & Molecular weight \\
\hline Rabbit Muscle Phosphorylase b & 97400 \\
Bovine Serum Albumin & 66200 \\
Chicken Ovalbumin & 45000 \\
Bovine Carbonic Anhydrase & 31000 \\
Soybean Trypsin Inhibitor & 21500 \\
Chicken Lysozyme & 14400 \\
\hline
\end{tabular}

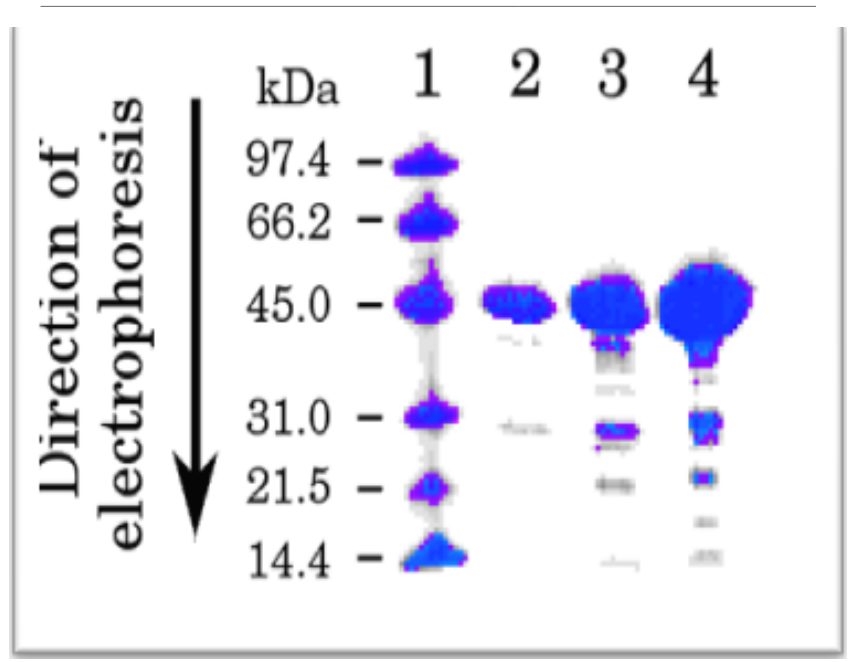

Figure 2 SDS-PAGE Protein Separation.

Gels have limits in terms of the amount of protein that can be loaded. Loading too much protein results in "overloading" in which the sample runs unevenly. Loading too little protein makes the protein bands difficult to detect. In choosing the amount of protein to load, you need to consider the number of proteins in your sample; if your sample contains many proteins, you can load more total protein (Figure 3).

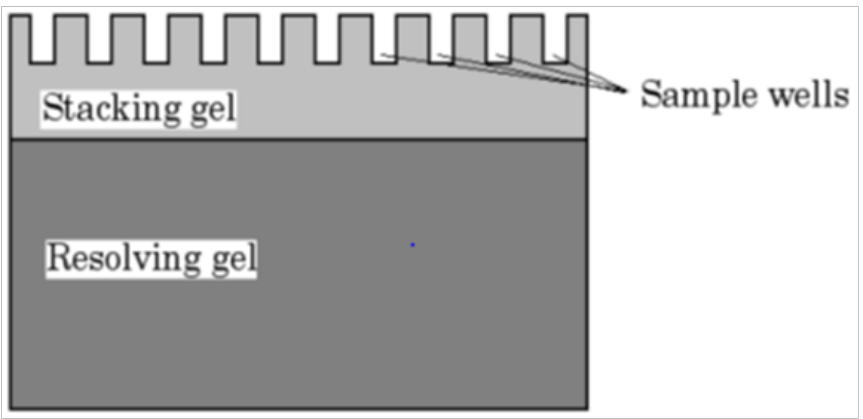

Figure 3 A picture of an SDS PAGE.

Chemicals required for SDS PAGE:

a) $\mathbf{1 0} \%$ Resolving gel

$1.5 \mathrm{ml} 1.5 \mathrm{M}$ Tris-HCl, $\mathrm{pH} 8.8$

$2 \mathrm{ml} 30 \%$ acrylamide

$0.06 \mathrm{ml} 10 \%$ SDS

$2.44 \mathrm{ml}$ water

Add last to initiate reaction:
$5 \quad 110 \%$ ammonium persulfate

$5 \mu 1$ TEMED

b) Stacking gel

$0.875 \mathrm{ml} 1.0$ M Tris-HCl, pH 6.8

$0.583 \mathrm{ml} 30 \%$ acrylamide

$0.035 \mathrm{ml} \mathrm{10 \%} \mathrm{SDS}$

$2.007 \mathrm{ml}$ water

Add last to initiate reaction:

$30 \mu 110 \%$ ammonium persulfate

$5 \mu 1$ TEMED

c) $5 x$ Sample Buffer

60mM Tris-HCl, pH 6.8

$25 \%$ glycerol

$2 \%$ SDS

14.4mM $\beta$-mercaptoethanol

$1 \%$ bromophenol blue

d) Electrophoresis tank buffer

$25 \mathrm{mM}$ Tris

192mM glycine, $\mathrm{pH} 8.8$

$0.1 \%$ SDS

Coomassie Staining Solution (10\% Acetic acid, 25\% Methanol, $0.05 \%$

Coomassie R-250 or Bio-Safe Coomassie Blue solution)

Electrophoretic techniques: Agarose gel electrophoresis DNA is a negatively charged molecule. Since all DNA sequences have the same phosphate backbone, fragments of all sizes have the same charge-tomass ratio. As with proteins, it is often useful to run DNA on gels. DNA gels are slightly different from protein gels. Because DNA has an intrinsically constant charge-to-mass ratio, addition of SDS is unnecessary. In addition, DNA fragments are generally much larger than protein molecules; in most cases, DNA is run on agarose gels instead of polyacrylamide gels, because agarose forms a lower density matrix more suited to running larger molecules..$^{20}$

Various concentrations of agarose can be used to separate different sized DNA: $0.75 \%$ for DNA $>3 \mathrm{~kb}, 2 \%$ or $3 \%$ for $50-400 \mathrm{bp}$, and $1 \%$ for DNA between these ranges. Agarose gels allow estimation of DNA fragment size. This can be useful for verifying that a fragment of the correct size was produced in a PCR reaction, or to assess the size of restriction enzyme digestion fragments. It is also useful to run plasmid DNA on a gel in order to assess both the concentration of the DNA and the quality of the preparation (i.e. to look for contaminating nucleic acids or excessive fragmentation of the plasmid DNA).

Agarose gels are usually run in either TBE (Tris-borate-EDTA) or TAE (Tris-acetate- EDTA) buffer. Because the agarose comprises a very small percentage of the gel while the remainder is the buffer, agarose gels can be run as "submarine gels", in which the gel is merely submerged in the buffer, with the electrical current running through both the buffer and the gel. 
Agarose gel procedure: Carefully seal the ends of casting tray. (The diagram below shows the ends sealed with tape; the apparatus you will probably be using is slightly different, and has its own built-in sealing mechanism.) Place the comb in position on the casting tray.

Mix the agarose and TBE at a ratio of $1 \mathrm{~g}$ agarose per $100 \mathrm{ml} \mathrm{TBE}$ and heat the solution in microwave oven until the agarose melts and is evenly distributed in the solution. Add $1 \mu \mathrm{l}$ of $10 \mathrm{mg} / \mathrm{ml}$ ethidium bromide for every $25 \mathrm{ml}$ of melted agarose. Allow the agarose to cool slightly (to avoid warping the plastic) and pour the agarose onto the casting tray.

After the gel cools (20minutes), remove the sealing tape and the comb. Place the casting tray with the gel into the electrophoresis apparatus, and add 1x TBE to just above the level of the gel. Load DNA samples containing 10\% loading Buffer. Run the gel under constant voltage conditions at 100 volts (Figure 4).

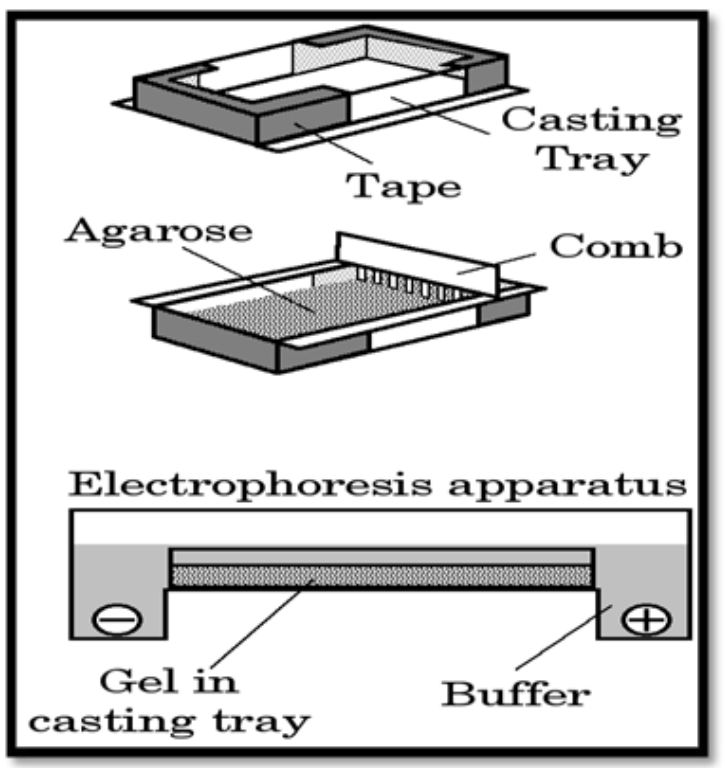

Figure 4 Basic procedures of Agarose.

\section{The art and science of protein purification}

When attempting to understand how a protein works, it is usually necessary to isolate the protein from other proteins that are present in the tissue. This allows you to study the protein with some assurance that the results reflect the protein of interest and are not due to other molecules that were originally present in the tissue. ${ }^{21}$

Protein purification is therefore a commonly used biochemical technique. Most proteins are fairly large molecules. They are smaller than DNA molecules, but they are tremendously large when compared to the molecules typical organic chemists are concerned with. The three-dimensional structure of most proteins is a consequence of many relatively weak non-covalent interactions. Disrupting this threedimensional structure, on which the function of the protein depends, is therefore a relatively easy process. Conversely, preventing the loss of the non-covalent structure (and sometimes the covalent structure) is frequently difficult. Disrupting cellular structure is required to release the proteins from the cell. However, the process has two side effects that may damage proteins: i. cell disruption typically involves shearing forces and heat, both of which can damage proteins

ii. cells normally contain proteases (enzymes that hydrolyze other proteins).

In most cells, proteases are carefully controlled; however, disruption of the cell usually also releases the proteases from their control systems, and may allow the cleavage of the protein of interest. Purification of proteins involves taking advantage of differences between the protein of interest and the remaining proteins present in the mixture. Because proteins are all polymers of the same twenty amino acids, the differences in properties tend to be fairly small. In most cases, current understanding of protein structural properties is insufficient to allow a purification method to be generated theoretically.

The "Art" in the title of this section reflects the fact that development of most protein purification procedures is a matter of trial and error. The table below lists some of the general properties of proteins that can be useful for protein purification, and some of the methods that take advantage of these properties. Each of these general methods will be discussed in some detail below. Note that for any given protein, only some of these methods will be useful, and therefore protein purification schemes vary widely.

Ammonium sulfate precipitation: In many cases, cell lysates can be loaded directly onto chromatography columns. However, in some cases other molecules present in the lysate interfere with binding of the protein to the resin. In addition, some resins (especially affinity resins and sepharose-based resins) are fairly expensive; loading crude cell lysates on these columns may result in binding of cellular material (e.g. lipids and DNA) that are difficult to remove, and which may damage the column. As a result, purification methods often begin with one of several possible simple techniques that remove at least some of these unwanted materials prior to using an expensive column. One of the most commonly used crude purification techniques involves the use of differential solubility. ${ }^{22}$

Proteins precipitate with increasing ammonium sulfate concentrations, with most proteins precipitating somewhere between $10 \%$ and $60 \%$ ammonium sulfate. (The percentages are relative to a saturated solution, which has a concentration of about $4 \mathrm{M}$; thus most proteins precipitate between $0.4 \mathrm{M}$ and $2.4 \mathrm{M}$.) This can allow a simple, partial, purification of a protein; if the protein of interest precipitates at $40 \%$ ammonium sulfate, many other proteins will remain in solution, as will many other non-protein molecules. Most proteins are not damaged by ammonium sulfate precipitation, and can be resuspended in a small volume of buffer. Ammonium sulfate precipitation results in a high salt concentration in the protein solution; this may be advantageous (if the intended next step is hydrophobic interaction chromatography), or deleterious (if the next step is ion exchange chromatography).

When necessary, two methods are frequently used to remove the salt. One method is gel filtration chromatography (discussed briefly below). Another frequently used method is dialysis.

Dialysis: Dialysis involves placing the protein solution in a semipermeable membrane, and placing the membrane in a large container of buffer. Small molecules (such as salt ions) pass through the dialysis membrane (moving from high concentration to low concentration), while large molecules are unable to cross the membrane. Dialysis membranes come in a variety of pore sizes, and are therefore useful for removing a variety of different sized solutes. In 
principle, dialysis could allow separation of large proteins from small ones; in practice, however, the pores in the tubing are insufficiently uniform to allow this technique to be used effectively (Figure 5).

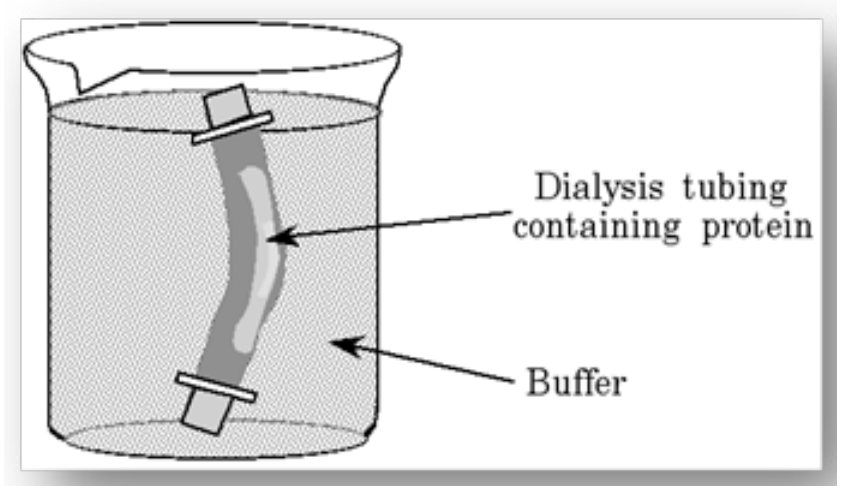

Figure 5 Dialysis membrane.

Chromatographic methods: Most purification methods involve chromatography. Chromatographic methods involve a column of an insoluble material that can bind molecules based on specific properties common to proteins. The solution containing the mixture of proteins is then allowed to pass through the column; the protein of interest may bind (depending on its properties), while at least some impurities remain in solution and leave the column. The procedure is completed by eluting (i.e. "removing") the proteins that have bound to the column.

An illustration of a chromatographic run is shown above. The initial sample contains five different proteins (the differently colored filled circles). These proteins are bound to the column fairly tightly. Once elution begins, the proteins begin leaving the column. The graph at the bottom of the diagram shows proteins eluting with increasing salt concentration, in the manner that would occur with an ion exchange column; otherwise, this diagram applies to essentially any type of chromatographic method. Note: most columns do not run this neatly, especially in the beginning of a purification procedure (Figure 6).

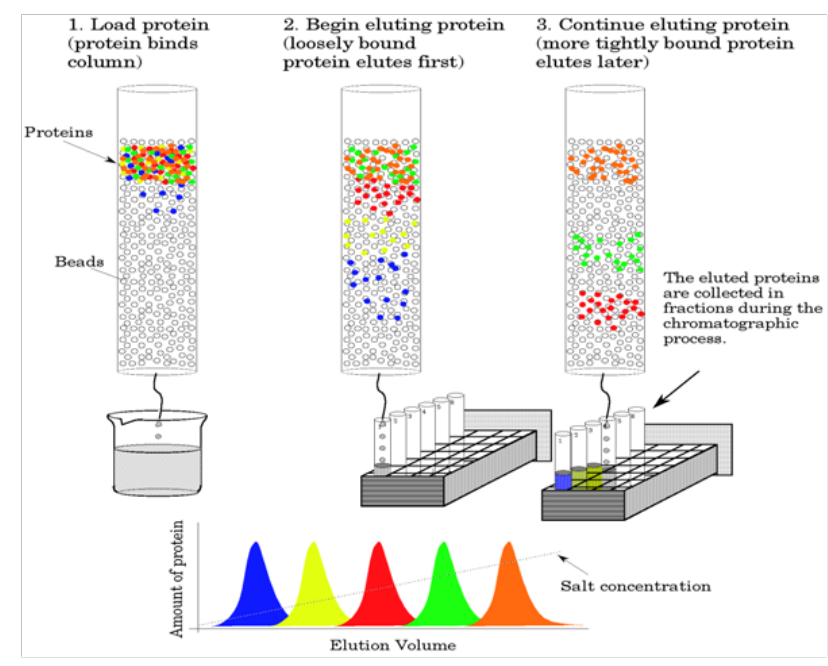

Figure 6 Chromatographic techniques of removing salt from protein.

\section{Ion exchange chromatography}

Proteins are charged molecules. They will therefore bind to other molecules of opposite charge. Ion exchange columns are produced by covalently attaching charged molecules such as diethyl-amino ethyl groups to insoluble carbohydrate resins. In many cases, small differences in charge can result in significant separations on ion exchange columns. Ion exchange columns are typically loaded at low ionic strength, and the protein removed by raising the ionic strength (Figure 7).

\section{Types of ion exchange chromatography}

Anion exchange chromatography

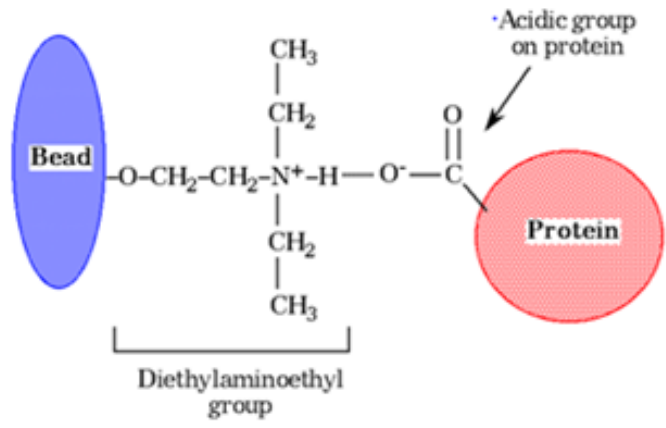

Cation exchange chromatography

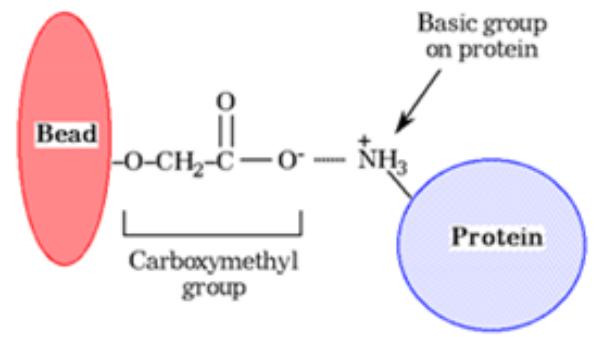

Figure 7 Protein purification using ion exchange chromatographic techniques.

\section{Acknowledgements}

The authors declare that there is no acknowledgment.

\section{Conflict of interest}

The authors declare that they have no conflict of interest.

\section{References}

1. Altan A. Isolation and Molecular Characterization of Extracellular Lipase and Pectinase Producing Bacteria from Olive Oil Mills. Turkey: Izmir Institute of Technology Izmir; 2004. 88 p.

2. Asad W, Asif M, Rasool SA. Extracellular enzyme production by indigenous thermophilic bacteria: partial purification and characterization of $\alpha$-amylase by Bacillus sp. WA21. Pak J Bot. 2011;43(2):1045-1052. 
3. D’Amico S, Marx JC, Gerday C, et al. Activity-Stability Relationships in Extremophilic Enzymes. J Biol Chem. 2003;278(10):7891-7896.

4. Dheeman DS, Henehan GT, Frías JM. Purification and properties of Amycolatopsis mediterranei DSM 43304 lipase and its potential in flavour ester synthesis. Bioresour Technol. 2011;102(3):3373-3379.

5. Gaurav P, Anil P, Pavania JVP, et al. Production, optimization and partia purification of protease from Bacillus subtilis. Journal of Taibah University for Science. 2015;9(1):50-55.

6. Gigi C, Adina C, Gabriela E, et al. Optimization of biosynthesis conditions and catalitic behavior evaluation of cellulase-free xylanase produced by a new streptomyces Sp. Strain. AUDJG-Food Technology. 2011;35(1):34-44.

7. Ishikawa H. Purification and characterization of organic solvent-stable protease from organic solvent-tolerant Pseudomonas aeruginosa PST01. J Biosci Bioeng. 1999;87(1):61-68.

8. Suriya J, Bharathiraja S, Krishnan M, et al. Marine Microbial Amylases: Properties and Applications. Adv Food Nutr Res. 2016;79:161-177

9. Kaur H, Dutt D, Tyagi CH. Production of novel alkali-thermotolerant cellulose-poor Xylanases from Coprinopsis cinerea WK-1 NF CC12032. BioResources. 2011;6(2):1376-1398.

10. Kohlmann KL, Nielson SS, Ladisch MR. Purification and characterization of an extracellular protease produced by Pseudomonas florescens M3/6. J Dairy Sci. 1991;74(12):4125-4136.

11. Lowry OH, Rosebrough NJ, Farr AL, et al. Protein measurement with the folin phenol reagent. J Bio Chem. 1951;193(1):265-273.

12. Maciel MHC, Herculano PN, Porto TS, et al. Production and partial characterization of pectinases from forage palm by Aspergillus niger URM4645. African Journal of Biotechnology. 2011;10(13):2469-2475.
13. McKevitt A, Bajaksouzian S, Klinger JD, et al. Purification and characterization of an extracellular protease from Pseudomonas cepacia. Infect Immun. 1989;57(3):771-778.

14. Miller GL. Use of dinitrosalicylic acid reagent for determination of reducing sugar. Anal Chem. 1959;31(3):426-428.

15. Natia K, Vladimir E, Solomon PW. Effect of Carbon, Nitrogen Sources, and Copper Concentration on the Ligninolytic Enzyme Production by Coriolopsis gallica. Journal of Waste Conversion, Bioproducts and Biotechnology. 2012;1(2):22-27.

16. Ogino H, Watanabe F, Yamada M, et al. Microbiology Concepts and Applications. USA: McGraw-Hill, Inc; 1993. p. 772-778.

17. Sexton MM, Jones AL, Chaowagul W, et al. Purification and characterization of a protease from Pseudomonas pseudomallei. Can J Microbiol. 1994;40(11):903-910.

18. Sohail M, Ahmad A, Ahmed Khan S. Production of cellulases from Alternaria sp. ms28 and their partial characterization. Pak J Bot. 2011;43(6):3001-3006.

19. Stepaniak L, Fox PF, Daly C. Isolation and general characterization of a heatstable proteinase from Pseudomonas fluorescens AFT 36. Biochim Biophys Acta. 1982;717(2):376-383.

20. Yandri AS, Suhartati T, Hadi S. Purification and Characterization of Extracellular $\alpha$-Amylase Enzyme from Locale Bacteria Isolate Bacillus Subtilis ITBCCB148. Euro J of Scientific Research. 2010;39(1):64-74.

21. Youssef GA. Physiological studies of cellulase complex enzymes of Aspergillus oryzae and characterization of carboxymethyl cellulose. African Journal of Microbiology Research. 2011;5(11):1311-1321.

22. Zambare VP, Nilegaonkar SS, Kanekar PP. Production of an alkaline protease by Bacillus cereus MCM B- 326 and its application as a dehairing agents. World J Microbiol Biotechnol. 2007;23(11):1569-1574. 